\title{
DETERMINASI STATUS SOSIAL EKONOMI ORANG TUA, MOTIVASI BERPRESTASI, DAN KETERSEDIAAN FASILITAS BELAJAR TERHADAP PRESTASI BELAJAR MATA PELAJARAN UN SISWA SMK NEGERI 1 PETANG
}

\author{
I Wayan Sucipta, .Made Yudana, I Gusti Ketut Arya Sunu. \\ 1.3Program Studi Administrasi Pendidikan, Program Pascasarjana \\ Universitas Pendidikan Ganesha \\ Singaraja, Indonesia \\ e-mail: \{wayansucipta@yahoo.com, made.yudana, arya.sunu\}, \\ @pasca.undiksha.ac.id
}

\begin{abstract}
Abstrak
Penelitian ini bertujuan untuk mengetahui determinasi status sosial ekonomi orang tua, motivasi berprestasi, dan ketersediaan fasilitas belajar terhadap prestasi belajar mata pelajaran UN siswa SMK Negeri 1 Petang. Penelitian ini adalah penelitian ex-post facto. Sampel penelitian ini sebanyak 56 siswa. Data status sosial ekonomi orang tua, motivasi berprestasi, dan ketersediaan fasilitas belajar dikumpulkan dengan metode kuesioner, sedangkan data prestasi belajar mata pelajaran UN dikumpulkan berdasarkan nilai ulangan umum semester siswa. Analisis data yang digunakan adalah analisis regresi sederhana, regresi ganda, dan korelasi partial. Berdasarkan penelitian yang telah dilakukan dapat disimpulkan bahwa: (1) terdapat determinasi yang signifikan status sosial ekonomi orang tua terhadap prestasi belajar mata pelajaran UN siswa SMK Negeri 1 Petang, dengan sumbangan efektif sebesar $22,06 \%$, (2) terdapat determinasi yang signifikan motivasi berprestasi terhadap prestasi belajar mata pelajaran UN siswa SMK Negeri 1 Petang, dengan sumbangan efektif sebesar $16,87 \%$, (3) terdapat determinasi yang signifikan ketersediaan fasilitas belajar terhadap prestasi belajar mata pelajaran UN siswa SMK Negeri 1 Petang, dengan sumbangan efektif sebesar $20,64 \%$, dan (4.) terdapat determinasi yang signifikan secara bersama-sama (simultan) status sosial ekonomi orang tua, motivasi berprestasi, dan ketersediaan fasilitas belajar terhadap prestasi belajar mata pelajaran UN siswa SMK Negeri 1 Petang, dengan sumbangan efektif sebesar $59,57 \%$.
\end{abstract}

Kata kunci: status sosial ekonomi orang tua, motivasi berprestasi, ketersediaan fasilitas belajar, prestasi belajar

\footnotetext{
Abstract

This research is aim to know the determination of Parents socio-economic status, achievement motivation, and the availability of learning facilities to the achievement National Examination subjects of the students of SMK Negeri 1 Petang. This research was ex-post facto. The sample of this research took 56 students. The data of Parents socio-economic status, achievement motivation, and the availability of learning facilities were collected by questionnaire method. While, the data of achievement study subject of the national examination were collected based on value of semester test. The analysis data which used was regression simple analysis, multiple regressions, and partial correlation. Based on the research that has been done can be concluded that: 1) there is a significant determinant of parent socio-economic status towards achievement National Examination subjects of the students of SMK Negeri 1 Petang, with the effective contribution of 22,06\%, (2) There is a significant determinant of achievement motivation towards achievement National Examination subjects of the students of SMK Negeri 1 Petang, with the effective contribution of $16,87 \%$, (3) There is a significant determinant of availability learning facilities towards learning achievement National Examination subjects of the students of SMK Negeri 1 Petang, with the effective contribution of $20,64 \%$, and (4) there is a simultaneously determination the socio-economic status of parents, achievement motivation, and the availability of learning facilities to the achievement National Examination subjects of the students of SMK Negeri 1 Petang, with the effective contribution of $59,57 \%$
} 
Keywords: socio-economic status, achievement motivation, availability facilities, academic achievement

\section{PENDAHULUAN}

Pendidikan dapat dianalogikan sebagai anak tangga mobilitas yang penting, maksudnya makin tinggi taraf pendidikan seseorang, makin besar kemungkinan mobilitas bagi anak-anak dari golongan ekonomi rendah dan menengah untuk meningkatkan kualitas SDM-nya. Upaya-upaya yang dimaksud, meliputi (1) usaha pembangunan serta pengembangan SDM secara optimal dan berkesinambungan agar mampu bersaing sekaligus bersanding dengan negara-negara lain, (2) mewujudkan mutu sekaligus kompeten yang berisi pengetahuan, kecakapan hidup dan nilai yang memadai, (3) menyiapkan SDM yang berkompeten secara utuh, dan senantiasa siap memperbaharui kompetensi, (4) menyiapkan generasi pembelajar yang peka terhadap perubahan. Hal tersebut mengindikasikan bahwa pembangunan SDM hanya dapat dilakukan melalui upaya pendidikan, baik di lingkungan keluarga (pendidikan infomal), sekolah (pendidikan formal), dan di lingkungan masyarakat (pendidikan nonformal).

Mengingat begitu pentingnya pendidikan, kini tanggung jawab terhadap pendidikan tidak lagi sepenuhnya dibebankan pada pundak pemerintah, namun sudah menjadi tanggung jawab bersama, baik orang tua siswa sendiri juga kalangan masyarakat luas. Agar pendidikan dapat terselenggara secara efektif dan efisien maka diperlukan suatu lembaga tempat berprosesnya pendidikan, sehingga tujuan pendidikan nasional dapat cepat terealisisasi. Kegiatan proses penyelenggaraan pendidikan tersebut tidak lain adalah lembaga formal yang dalam hal ini adalah sekolah. Sekolah adalah suatu lembaga yang mampu memberikan pembelajaran.

Dalam kegiatan belajar, unsur proses belajar memegang peranan penting karena sejatinya inti dari kegiatan pendidikan adalah kegiatan belajar mengajar. Selanjutnya dari kegiatan belajar mengajar akan dihasilkan sebuah produk yang disebut prestasi belajar. Prestasi belajar adalah hasil yang dicapai oleh seseorang dalam kegiatan belajar (Partini, 1980: 49).

Semua pelaku pendidikan (siswa, orang tua, dan guru) pasti menginginkan tercapainya sebuah prestasi belajar yang tinggi, karena prestasi belajar yang tinggi merupakan salah satu indikator keberhasilan proses belajar. Pada kenyataannya tidak semua siswa mendapatkan prestasi belajar yang tinggi, namun sebaliknya ada pula berprestasi belajar rendah. Tinggi dan rendahnya prestasi belajar yang diperoleh siswa dipengaruhi oleh banyak faktor.

Syah (2005:146), mengutarakan bahwa ada dua faktor yang menentukan keberhasilan dalam proses belajar mengajar yaitu faktor yang berasal dari dalam diri siswa (faktor internal) dan dari luar diri siswa (faktor eksternal). Faktor internal meliputi kecerdasan, bakat dan motivasi, minat belajar diri siswa itu sendiri. Sedangkan faktor eksternal meliputi: status sosial ekonomi orang tua, kemampuan guru dalam menerangkan pelajaran, ketersediaan fasilitas belajar di rumah, lingkungan, dan lain-lain.

Pandangan tentang keterkaitan status sosial ekonomi orang tua dengan perkembangan belajar anak juga diungkapkan Gerungan (1991:181), yang menyatakan bahwa status sosial ekonomi keluarga mempunyai peranan terhadap perkembangan anakanak. Dengan adanya perekonomian yang cukup, lingkungan material yang dihadapi anak di dalam keluarganya lebih luas dan akan mendapat kesempatan yang lebih luas pula dalam mengembangkan berbagai macam kecakapan dan dukungan perekonomian yang memadai, anak akan lebih mudah mengikuti proses pembelajaran di sekolah karena semua fasilitas belajar penopang dalam proses pembelajaran dapat terpenuhi oleh orang tuanya. Terlepas seberapa besar determinasi faktor internal dan eksternal terhadap kemajuan dan perkembangan prestasi belajar siswa sebagaimana dipaparkan oleh para ilmuwan di atas, yang terpenting adalah mencari jawaban bagaimana solusi untuk mengatasi permasalahan dunia pendidikan di Tanah Air yang saat ini masih belum beranjak dari keterpurukan.

Memperhatikan hasil survey yang dilaksanakan oleh Human Devolopment Index UNDP Tahun 2004, peringkat mutu pendidikan Indonesia untuk semua jenjang sekolah, hanya 
mampu bertengger di urutan ke-111. Tertinggal jauh dengan negara-negara tetangga di kawasan Asia Tenggara seperti; Malaysia urutan (58), Thailand (76), serta Philipina (83). Meskipun penelitian yang dilaksanakan oleh lembaga peneliti tersebut sudah lama yang barangkali tidak relevan lagi, setidaknya dapat dijadikan gambaran seperti itulah jejak rekam pendidikan kita. Akurat atau tidak akuratnya hasil survey tersebut, fakta di lapangan menyatatakan Ujian Nasional (UN) sebagai model evaluasi baru yang dijadikan standar nasional untuk mengetahui kualitas pendidikan di Indonesia, terindikasi prestasi belajar yang diperoleh peserta UN memang belum memuaskan.

Data empirik yang diperoleh di SMK Negeri 1 Petang, rerata nilai ujian pemantapan tingkat Kabupaten Badung pada mata pelajaran yang di-UN-kan pada Tahun Pelajaran 2014/2015 menunjukkan, nilai Bahasa Indonesia tercatat $(4,80)$, Bahasa Inggris $(5,36)$, dan yang lebih tragis lagi yakni Matematika hanya $(2,24)$. Sementara untuk tingkat Provinsi Bali, mata pelajaran Bahasa Indonesia nilai rata-rata yang diraih siswa tercatat $(4,93)$, Bahasa Inggris (4,25), Matematika (2,07), dan Kompetensi Keahlian/Kejuruan (8,00). Malah belakangan ini, UN disinyalemen banyak dipolitisasi oleh pihak-pihak tertentu yang berkepentingan sehingga nilai UN sudah tidak murni lagi. Dengan demikian nilai UNtidak dapat dijadikan acuan untuk mengukur kualitas pendidikan di Indonesia. Bahkan, di tengahtengah kegalauan tersebut, kini pemerintah lagi-lagi mengeluarkan kebijakan yang masih bersifat pro dan kontra, berupa Permendikbud Republik Indonesia Nomor 5 Tahun 2015 tentang "Kriteria kelulusan peserta didik penyelenggaraan UN dan penyelenggaraan ujian Sekolah/Madrasah /SMP/MTs atau yang sederajat dan SMA/MA/SMK atau yang sederajat". Pada intinya nilai UN tidak lagi menentukan kelulusan peserta didik. Kelulusan peserta didik sepenuhnya menjadi kewenangan pihak satuan pendidikan. Hal ini oleh beberapa pihak ditengarai akan semakin memperburuk keadaan, lantaran menurunnya motivasi belajar siswa. Begitu kompleksnya faktor yang menentukan prestasi belajar siswa, maka fokus kajian dalam penelitian ini yang diduga berhubungan dengan prestasi belajar siswa adalah motivasi berprestasi sebagai faktor internal, dan ketersediaan fasilitas belajar, serta status sosial ekonomi orang tua siswa sebagai faktor eksternal. Dilibatkannya motivasi berprestasi yang diduga berhubungan dengan prestasi belajar, karena motivasi merupakan dorongan yang terdapat dalam diri seseorang untuk berusaha mengadakan perubahan tingkah laku yang lebih baik dalam memenuhi kebutuhannya (Hamzah B. Uno, 2013:3).

Di era persaingan seperti saat ini, beberapa sekolah khususnya untuk jenjang Sekolah Menengah Kejuruan (SMK), dua unsur yang disebutkan tadi yaitu status sosial ekonomi orang tua dan ketersediaan fasilitas belajar kerap menjadi batu sandungan dalam upaya meningkatkan prestasi belajar siswa, karena orang tuanya tidak mampu menyediakan fasilitas belajar yang memadai. Terbatasnya dukungan dari faktor ekonomi, seperti dikemukakan Abu Ahmadi dan Widodo Supriyono (2004:88) yang menyatakan bahwa keadaan ekonomi keluarga akan mempengaruhi ketersediaan fasilitas belajar.

Permasalahan tersebut, dialami pula para siswa SMK Negeri 1 Petang, dimana ketersediaan fasilitas pembelajaran yang dimiliki tergolong minim. Siswa sebagian besar tidak memiliki buku pelajaran pegangan sendiri. Siswa kebanyakan mengandalkan bukubuku/modul/LKS yang disiapkan oleh pihak sekolah. Di sisi lain, pihak sekolah juga belum mampu sepenuhnya menyediakan buku-buku pelajaran di perpustakaan. Ketersediaan buku-buku pelajaran masih jauh dari harapan. Sebagai ilustrasi, siswa yang saat ini terdiri dari 13 (tiga belas) rombongan belajar (rombel), baru memiliki 6 (enam) ruang belajar, sehingga untuk mengatur tempat pembelajaran pihak sekolah menerapkan moving class (kelas bepindah-pindah). Cara ini pun sewaktu-waktu kerap mengalami hambatan, dan pihak sekolah tidak segan-segan menggunakan laboratorium untuk kegiatan pembelajaran. Tidak hanya untuk pembelajaran di kelas, pembelajaran praktik (di laboratorium) juga belum didukung fasilitas yang memadai. SMK Negeri 1 Petang saat inibaru memiliki lahan untuk sarana praktikum sekitar 50 are. Padahal, bagi program studi keahlian ini, lahan merupakan fasilitas pembelajaan yang sangat vital. Begitu pula pada program studi keahlian agribisnis hasil pertanian (AHP), peralatan, dan bahan-bahan untuk mendudukng proses pembelajaran 
hingga dihasilkan produk yang lebih banyak dan berkualitas juga masih menjadi permasalahan cukup serius.

Terkait dengan keberadaan kondisi ekonomi orang tua siswa yang diperoleh berdasarkan informasi dari beberapa tokoh masyarakat Desa Pelaga, mengatakan sebagian besar mata pencaharian bersumber dari bertani dengan penghasilan Rp 500.000 - Rp 1.000.000 perbulan. Jika ditinjau dari taraf pendidikan orang tua siswa, komposisinya adalah tamatan SMA/SMKsekitar 50\%, SMP (30\%), SD (15\%), dan S1 (5\%). Demikian pula halnya dengan animo orang tua dalam menyediakan fasilitas belajar, masih tergolong relatif rendah sehingga berdampak pada motivasi berprestasi serta prestasi belajar mata pelajaran UN para putra-putrinya.

Bertitik tolak dari fenomena di atas, dipandang perlu untuk membuktikan secara empirik melalui penelitian tentang determinasi status sosial ekonomi orang tua, motivasi berprestasi, dan ketersediaan fasilitas belajar terhadap prestasi belajar mata pelajaran UN siswa SMK Negeri 1 Petang.

\section{METODE PENELITIAN}

Ditinjau dari pendekatannya, penelitian ini termasuk pendekatan kuantitatif dengan rancangan korelasional karena dalam penelitian ini mencoba untuk mengetahui hubungan sebab akibat yang titik beratnya pada variabel yang dikorelasikan. Penelitian ini dikategorikan penelitian non-eksperimen (ex post facto), lantaran gejala-gejala yang diteliti sudah ada secara wajar pada subjek penelitian.

Dalam penelitian ini, populasi yang diteliti adalah siswa SMK Negeri 1 Petang di Kecamatan Petang, khususnya kelas XI dari Program Keahlian Agribisnis Hasil Pertanian (AHP) yang terdiri atas kelas XI AHP1 dan AHP2, serta kelas XI dari Program Keahlian Agribisnis Produksi Tanaman (APT) yang terdiri dari kelas APT1 dan APT2. Adapun jumlah dari populasi penelitian ini adalah 114 orang siswa. Sampel yang digunakan dalam penelitian ini berjumlah 56 orang siswa.

Penelitian ini bertjuan untuk meneliti hubungan antarvariabel. Variabel-variabel yang dimaksudkan dalam penelitian ini terdiri atas tiga variabel bebas (independent variable) yaitu: status sosial ekonomi orang tua $\left(X_{1}\right)$, motivasi berprestasi $\left(X_{2}\right)$, ketersediaan fasilitas belajar $\left(\mathrm{X}_{3}\right)$, dan variabel terikat (dependent variable) yaitu prestasi belajar $(\mathrm{Y})$.

Untuk mengukur keempat variabel tersebut dilakukan menggunakan kuesioner. Kuesioner yang digunakan menggunakan skala likert 1-5. Berdasarkan uji coba instrumen yang telah dilakukan, dinyatakan bahwa seluruh butir tiap-tiap variabel valid dengan tingkat reliabilitas sangat tinggi.

Data hasil penelitian yang telah terkumpul perlu dideskripsikan terlebih dahulu sehingga memudahkan pemahamannya. Untuk keperluan ini data status sosial ekonomi orang tua, motivasi berprestasi, ketersediaan fasilitas belajar dan prestasi belajar dideskripsikan dengan statistik deskriptif. Statistik deskriptif adalah statistik yang digunakan untuk menganalisis data dengan cara mendeskripsikan atau menggambarkan data yang telah terkumpul sebagaimana apa adanya tanpa bermaksud membuat kesimpulan yang berlaku untuk umum atau generalisasi.

Setelah data selesai dideskripsikan, analisis dilanjutkan kedalam uji persyaratan analisis. Uji persyaratan analisis yang dilakukan adalah: 1) uji normalitas sebaran data, 2) uji linieritas dan keberartian arah koefisien regresi, 3) uji multikolinieritas, 4) uji autokorelasi, dan 5) uji heterokedastisitas.

Setelah data dalam penelitian ini memenuhi uji persyaratan analisis, analisis dilanjutkan ke uji hipotesis. Untuk menguji hipotesis pertama, kedua, dan ketiga digunakan teknik analisis regresi sederhana, sedangkan untuk menguji hipotesis keempat digunakan teknik analisis regresi ganda tiga prediktor dan analisis korelasi ganda.

\section{HASIL PENELITIAN DAN PEMBAHASAN}

\section{Determinasi Status Sosial Eekonomi Orang Tua Terhadap Prestasi Belajar Siswa Kelas XI SMK Negeri 1 Petang}


Berdasarkan analisis yang telah dilakukan, Secara normatif ditemukan bahwa status sosial ekonomi orang tua berada pada kategori sedang. Selain itu, hasil analisis juga menunjukkan bahwa terdapat determinasi yang signifikan antara status sosial ekonomi orang tua dengan prestasi belajar di SMK Negeri 1 Petang melalui persamaan garis regresi ŷ $=60,554+0,237 \mathrm{X} 1$ dengan Freg $=31,215(\mathrm{p}<0,05)$. Korelasi antara status sosial ekonomi orang tua dengan prestasi belajar adalah signifikan yakni sebesar 0,605 dengan $p<0,05$. Ini berarti makin baik status sosial ekonomi orang tua, makin baik prestasi belajar tersebut. Variabel status sosial ekonomi orang tua dapat menjelaskan makin tinggi prestasi belajar siswa kelas XI di SMK Negeri 1 Petang sebesar 36,6\%.Temuan ini mengindikasikan bahwa status sosial ekonomi orang tua mempunyai peranan penting dalam meningkatkan prestasi belajar. Sumbangan efektif (SE) variabel status sosial ekonomi orang tua terhadap prestasi belajar di SMK Negeri 1 Petang sebesar 22,06\%.

Hasil penelitian ini sejalan dengan hasil penelitian yang dilakukan oleh Dewa Putu Sastrayasa (2015) yang melakukan penelitian dengan judul "Analisis tentang Biaya Pendidikan Ditinjau dari Status Sosial Ekonomi Orang Tua Siswa Sekolah Dasar di Desa Cemagi dalam Pengaruhnya Terhadap Hasil Belajar Siswa", memberikan kesimpulan ada pengaruh secara simultan biaya pendidikan ditinjau dari status sosial ekonomi orang tua SD di Desa Cemagi terhadap hasil belajar siswa. Hal tersebut ditunjukkan melalui Uji F diperoleh $\mathrm{F}$ hitung sebesar 3,866 sedangkan $\mathrm{F}$ tabel 0,008 , artinya $\mathrm{F}$ hitung $>$ dari $\mathrm{F}$ tabel pada derajat kepercayaan $5 \%(0,05)$. Ini berarti bahwa Ho ditolak sehingga dapat dikatakan ada pengaruh yang signifikan secara simultan antara biaya pendidikan dengan hasil belajar siswa.

Selanjutnya penelitian yang dilakukan oleh Aryadewi (2012) yang berjudul determinan motivasi kerja, status sosial ekonomi, dan pola asuh orang tua terhadap niat berwiraswasta siswa SMK Pariwisata Triatma Jaya Dalung Kabupaten Badung Propinsi Bali. Dalam penelitiannya dinyatakan bahwa 1) terdapat determinasiyang signifikan antara motivasi kerja terhadap niat berwiraswasta siswa SMKPariwisata Triatma Jaya Dalung Kabupaten Badung. melalui persamaan regresiY ${ }^{\wedge}=61.107+0.332 \times 1.2$ ) terdapat determinasi yang signifikan antara status sosialekonomi dengan niat berwiraswasta siswa SMK Pariwisata Triatma Jaya DalungKabupaten Badung. Untuk menguji hipotesis ini digunakan tehnik analisis regresibivariat, analisis yang dilakukan menghasilkan persamaan regresi $Y^{\wedge}=81.148+$ 0.152 X2. 3) terdapat determinasi yang signifikan antara pola asuh orang tuadengan niat berwiraswasta siswa SMK Pariwisata Triatma Jaya DalungKabupaten Badung. Untuk menguji hipotesis ini digunakan tehnik analisis regresibivariat, analisis yang dilakukan menghasilkan persamaan regresi $Y^{\wedge}=85.467+0.119 X 3$. 4) terdapat determinasi yang signifikan secara bersama-sama antaramotivasi kerja, status sosial ekonomi, dan pola asuh orang tua dengan niat berwiraswasta siswa SMK Pariwisata Triatma Jaya Badung. Untuk menguji hipotesis ini digunakan tehnik analisis regresi bivariat. Analisis yang dilakukan menghasilkan persamaan regresi $Y^{\wedge}=47.772+0,304 X 1+0,107 X 2+0,100 X 3$. Berdasarkan hasil tersebut, dapat disimpulkan bahwa terdapat determinasi yang signifikan faktor non intelek yaitu motivasi kerja, status sosial ekonomi, pola asuh orang tua terhadap niat berwiraswasta siswa SMK Pariwisata Triatma Jaya Dalung Kabupaten Badung Propinsi Bali.

Adapun faktor-faktor yang menentukan keberhasilan dalam proses belajar mengajar terdiri atas dua macam yaitu: faktor yang berasal dari dalam diri siswa (faktor internal) dan dari luar diri siswa (faktor eksternal). Faktor internal meliputi kecerdasan, bakat dan motivasi, minat belajar diri siswa itu sendiri, sedangkan faktor eksternal meliputi status sosial ekonomi orang tua, kemampuan guru dalam menerangkan pelajaran, ketersediaan fasilitas belajar di rumah, lingkungan dan lain-lain (Syah, 2005).

Mengutip pendapat Syah, faktor status sosial ekonomi orang tua ternyata memiliki peranan penting dan mempunyai hubungan yang positif terhadap peningkatan prestasi atau hasil belajar siswa di sekolah. Pasalnya, dalam mendukung proses pembelajaran di sekolah dukungan finansial untuk pengadaan alat-alat atau seperangkat pengajaran atau pembelajaran adalah hal yang tidak bisa ditawar-tawar lagi. Sebagaimana diketahui, alat-alat 
pembelajaran tersebut dapat dijadikan sarana untuk memudahkan siswa dalam mendapatkan informasi, dan pengelolaan bahan pelajaran yang diperoleh dari sekolah.

Bertolak dari pendapat sejumlah sumber di atas, Koyan (dalam Udiana, 2009:23) mengatakan: "Status sosial ekonomi seseorang dalam masyarakat ditentukan oleh beberapa indikator antara lain; tingkat pendidikan, jenis pekerjaan, kekayaan, kehormatan atau jabatan-jabatan sosial lainnya".

Berdasarkan uraian di atas, dapat disimpulkan bahwa terdapat determinasi antara status sosial ekonomi orang tua sebagai faktor eksternal terhadap prestasi belajar mata pelajaran UN siswa SMK Negeri 1 Petang.

\section{Determinasi Motivasi Berprestasi Terhadap Prestasi Belajar Siswa Kelas XI SMK Negeri 1 Petang}

Berdasarkan analisis yang telah dilakukan, secara normatif ditemukan bahwa motivasi berprestasi berada pada kategori sangat tinggi. Selain itu, hasil analisis juga menunjukkan bahwa terdapat korelasi yang signifikan antara motivasi berprestasi dengan prestasi belajar siswa kelas XI SMK Negeri 1 Petang melalui persamaan garis regresi $\hat{y}=$ $26,748+0,297$ X2 dengan Freg $=29,493(p<0,05)$. Korelasi antara motivasi berprestasi dengan prestasi belajar adalah signifikan yakni sebesar 0,594 dengan $p<0,05$. Ini berarti makin baik motivasi berprestasi, makin baik prestasi belajar tersebut. Variabel motivasi berprestasi dapat menjelaskan makin tinggi prestasi belajar di SMK Negeri 1 Petang sebesar $35,3 \%$. Temuan ini mengindikasikan bahwa motivasi berprestasi mempunyai peranan penting dalam meningkatkan prestasi belajar. Sumbangan efektif (SE) variabel Motivasi berprestasi terhadap prestasi belajar di SMK Negeri 1 Petang sebesar 16,87\%.

Hasil penelitian ini sejalan dengan hasil penelitian yang dilakukan oleh Sukada (2013) yang berjudul kontribusi minat belajar, motivasi berprestasi dan kecerdasan logis matematika terhadap hasil belajar matematika siswa SMA Negeri 1 Kintamani. Dalam penelitiannya dinyatakan bahwa (1). Minat belajar berkontribusi terhadap hasil belajar matematika dengan kontribusi sebesar $11,80 \%$, (2). Motivasi berprestasi siswa berkontribusi terhadap hasil belajar matematika siswa dengan kontribusi sebesar 6,00\%. (3). Kecerdasan logis matematika berkontribusi terhadap hasil belajar matematika dengan kontribusi sebesar $6,20 \%$. (4). Variabel minat belajar siswa, motivasi berprestasi siswa, dan kecerdasan logis matematika siswa secara bersama-sama berkontribusi signifikan terhadap hasil belajar matematika siswa dengan kontribusi sebesar $26,6 \%$. Berdasarkan temuan tersebut dapat disimpulkan, bahwa secara terpisah atau bersama-sama terdapat kontribusi signifikan antara minat, motivasi berprestasi, kecerdasan logis matematika terhadap hasil belajar matematika siswa Kelas XI Jurusan IPA, IPB, dan IPS SMA Negeri 1 Kintamani.

Motivasi berprestasi adalah suatu daya penggerak atau pendorong dalam diri seseorang (siswa) untuk melakukan suatu tindakan sehingga dapat mencapai prestasi belajar yang sebaik-baiknya berdasarkan suatu ukuran tertentu. Motivasi berprestasi dapat dikatakan sebagai standard of exellence yaitu kecenderungan individu untuk mencapai prestasi secara optimal (McClelland, 1987).

Haditono (dalam Kumalasari, 2006), menekankan motivasi berprestasi sebagai kecenderungan untuk meraih prestasi dalam hubungan dengan nilai standar keunggulan. Herman lewat Linda (2004), menggaris bawahi motivasi berprestasi ini sangat penting dalam kehidupan sehari-hari, karena motif berprestasi akan mendorong seseorang untuk mengatasi tantangan atau rintangan dan memecahkan masalah seseorang, bersaing secara sehat, serta akan berpengaruh pada prestasi kerja seseorang.

Sardiman (2011:84-85) menegaskan, bahwa dalam belajar sangat diperlukan adanya motivasi. Prestasi belajar akan menjadi optimal kalau ada motivasi. Makin tepat motivasi yang diberikan, akan makin berhasil pula pelajaran itu.

Memperhatikan ulasan terkait motivasi berprestasi tinggi sebagaimana telah dikemukakan sebelumnya, Degeng mendefinisikan motivasi berprestasi sebagai usaha siswa untuk mendapatkan nilai yang tinggi di sekolah, dengan ciri-ciri sebagai berikut: (1) selalu aktif mengikuti pelajaran, (2) berpartisifasi aktif dalam diskusi, (3) mengikuti pelajaran 
dengan tepat waktu, (4) mengerjakan tugas-tugas dengan usaha sendiri, (5) mengumpulkan tugas-tugas tepat waktu, (6) aktif membuat ringkasan, (7) gemar membaca, baik bukuwajib maupun anjuran, dan (8) sebagian besar waktunya untuk belajar.

Berdasarkan pemaparan di atas, dapat disimpulkan bahwa terdapat determinasi yang signifikan antara motivasi berprestasi dengan prestasi belajar mata pelajaran UN siswa SMK Negeri 1 Petang.

\section{Determinasi Ketersediaan Fasilitas Belajar Terhadap Prestasi Belajar Siswa Kelas XI SMK Negeri 1 Petang}

Berdasarkan analisis yang telah dilakukan, secara normatif ditemukan bahwa ketersediaan fasilitas belajar berada pada kategori baik. Selain itu, hasil analisis juga menunjukkan bahwa terdapat korelasi yang signifikan antara ketersediaan fasilitas belajar dengan prestasi belajar siswa kelas XI SMK Negeri 1 Petang melalui persamaan garis regresi $\hat{y}=48,963+0,258 \times 3$ dengan Freg $=32,392(p<0,05)$. Korelasi antara ketersediaan fasilitas belajar dengan prestasi belajar adalah signifikan yakni sebesar 0,612 dengan $p<0,05$. Ini berarti makin lengkap fasilitas belajar, makin baik prestasi belajar tersebut. Variabel fasilitas belajar dapat menjelaskan makin tinggi prestasi belajar di SMK Negeri 1 Petang sebesar $37,5 \%$. Temuan ini mengindikasikan bahwa ketersediaan fasilitas belajar mempunyai peranan penting dalam meningkatkan prestasi belajar. Sumbangan efektif (SE) variabel ketersediaan fasilitas belajar terhadap prestasi belajar di SMK Negeri 1 Petang sebesar $20,64 \%$.

Hasil penelitian ini sejalan dengan hasil penelitian yang dilakukan oleh Katili (2013) yang berjudul Analisis Sarana dan Intensitas Penggunaan Laboratorium Fisika Serta Kontribusinya Terhadap Hasil Belajar Siswa SMA Negeri di Kabupaten Jembrana. Dalam penelitiannya dinyatakan bahwa: berdasarkan hasil analisis terhadap bahan dan alat ukur dasar serta fasilitas alat percobaan menunjukkan secara umum belum memenuhi standar minimal sesuai Permendiknas No 24 tahun 2007 tentang standar sarana dan prasarana, kompetensi kepala laboratorium dalam hal kepribadian sudah dalam kualifikasi baik, sedangkan kompetensi sosial, manajerial, serta profesional masih dalam kualifikasi kurang.tenaga teknisi laboran belum tersedia, used factor alat hanya 12,08\% (sangat kurang), dan data rata-rata hasil belajar siswa 34,4 dalam kualifikasi kurang.

Salah satu faktor ekstern yang mempengaruhi prestasi belajar adalah ketersediaan fasilitas belajar di sekolah. Proses belajar mengajar yang tidak dilengkapi dengan fasilitas yang baik dan memadai maka proses belajar mengajar di sekolah tidak akan berjalan maksimal seperti yang diinginkan. Begitu pula sebaliknya proses belajar di sekolah yang dilengkapi dengan fasilitas yang memadai diharapkan dapat membantu proses belajar sehingga dapat meningkatkan kualitas prestasi belajar. Ketersediaan fasilitas belajar yang memadai merupakan penunjang belajar siswa untuk memudahkan dan memperlancar kegiatan belajar di sekolah maupun di rumah. Fasilitas belajar tersebut dapat berupa sumber belajar, ruang dan tempat belajar, media atau alat bantu belajar, perpustakaan, dan lain-lain.

Kartono (1985:6) menyebutkan bahwa, "Lengkap tidaknya perlengkapan belajar baik yang dimiliki siswa maupun yang dimiliki sekolah dapat menimbulkan hasil tertentu terhadap hasil belajar siswa, kekurangan peralatan belajar dapat membawa akibat negatif antara lain, murid tidak bisa belajar secara baik sehingga sulit diharapkan mencapai prestasi tinggi".

Sehubungan dengan hal tersebut, The Liang Gie (2002) mempertegas setidaknya ada empat jenis fasilitas belajar yang harus ada agar proses belajar dapat berjalan dengan baik. Keempat fasilitas belajar tersebut adalah: (1) ruang tempat belajar yang nyaman, (2) penerangan yang baik, (3) buku-buku pegangan yang lengkap, dan (4) kelengkapan peralatan belajar lainnya yang memadai.

Berdasarkan pemaparan di atas, dapat disimpulkan bahwa terdapat determinasi yang signifikan antara ketersediaan fasilitas belajar terhadap prestasi belajar mata pelajaran UN siswa SMK Negeri 1 Petang. 


\section{Secara Bersama-Sama, Determinasi Status Sosial Ekonomi Orang Tua, Motivasi Berprestasi dan Ketersediaan Fasilitas Belajar Terhadap Prestasi Belajar Siswa Kelas XI SMK Negeri 1 Petang}

Berdasarkan analisis yang telah dilakukan, ditemukan bahwa secara bersama-sama terdapat korelasi yang signifikan antara status sosial ekonomi orang tua, motivasi berprestasi, dan fasilitas belajar terhadap prestasi belajar melalui persamaan garis regresi $\hat{y}$ $=26,835+0,143 X 1+0,142 X 2+0,142 X 3$ dengan Freg $=25,456(p<0,05)$. Ini berarti, makin baik status sosial ekonomi orang tua, motivasi berprestasi, dan fasilitas belajar, makin baik pula prestasi belajar tersebut.

Kecendrungan status sosial ekonomi orang tua memberikan determinasi terhadap prestasi belajar siswa cukup berdasar, karena tanpa didukung oleh kemapanan perekonomian orang tua, mustahil mampu memenuhi keperluan anak yang semakin kompleks, terlebih dikaitkan dengan kegiatan pembelajaran.

Pandangan tentang keterkaitan status sosial ekonomi orang tua dengan perkembangan belajar anak menurut Gerungan (1991:181), adalah status sosial ekonomi keluarga mempunyai peranan terhadap perkembangan anak-anak. Dengan adanya perekonomian yang cukup, lingkungan material yang dihadapi anak didalam keluarganya lebih luas akan mendapat kesempatan yang lebih luas untuk mengembangkan berbagai macam kecakapan yang tidak dapat berkembang jika tidak ada alat-alatnya. Anak akan dengan mudah mengikuti proses belajar pada saat di sekolah, lantaran semua fasilitas belajar atau sarana dan prasarana pendukung dari proses pembelajaran dapat terpenuhi oleh orang tuanya. Sebaliknya, ketika status sosial ekonomi keluarga rendah maka anak akan mengalami kesulitan dalam mengikuti proses pembelajaran di sekolah, karena sarana dan prasarana pendukung dari proses pembelajaran tidak terpenuhi oleh orang tuanya.

Dukungan ekonomi yang memadai dari orang tua, juga memiliki kaitan yang sangat erat dengan munculnya motivasi berprestasi siswa dalam upaya meningkatkan prestasi belajar siswa atau putra-putrinya. Para orang tua dengan kelebihan perekonomiannya memiliki peluang yang lebih besar untuk memacu motivasi berprestasi serta mengarahkan pada putra-putrinya untuk meningkatkan kualitas diri.

McClelland (1976), mengisyaratkan orang tua yang memiliki standar kualitas tinggi menganjurkan anak-anaknya akan meningkatkan motivasi berprestasi yang tinggi pada anak. Motivasi beprestasi anak muncul jika ditopang fasilitas belajar yang memadai. Fasilitas belajar erat hubungannya dengan motivasi belajar, dengan adanya ketersediaan fasilitas belajar yang lengkap, anak dengan sendirinya akan termotivasi melakukan aktivitas belajar yang pada akhirnya akan menentukan keberhasilan belajar siswa. Jadi, sukses tidaknya siswa dalam meningkatkan kualitas prestasi belajarnya, di samping lantaran kontribusi dari kemampuan perekonomian orang tuanya, juga oleh motivasi berprestasi yang muncul dari dirinya sendiri serta sokongan ketersediaan fasilitas belajar yang memadai, baik oleh orang tua di rumahnya sendiri maupun oleh sekolah saat proses pembelajaran dilaksanakan.

\section{PENUTUP} berikut.

Berdasarkan penelitian yang telah dilakukan, dapat disimpulkan hal-hal sebagai

1. Terdapat determinasi yang signifikan status sosial ekonomi orang tua terhadap prestasi belajar mata pelajaran UN siswa SMK Negeri 1 Petang. Dengan determinasi sebesar $36,6 \%$ dan sumbangan efektif sebesar $22,06 \%$.

2. Terdapat determinasi yang signifikan motivasi berprestasi terhadap prestasi belajar mata pelajaran UN siswa SMK Negeri 1 Petang. Dengan determinasi sebesar 35,3\% dan sumbangan efektif sebesar $16,87 \%$.

3. Terdapat determinasi yang signifikan ketersediaan fasilitas belajar terhadap prestasi belajar mata pelajaran UN siswa SMK Negeri 1 Petang. Dengan determinasi sebesar $37,5 \%$ dan sumbangan efektif sebesar $20,64 \%$. 
4. Terdapat determinasi secara bersama-sama (simultan) status sosial ekonomi orang tua, motivasi berprestasi, dan ketersediaan fasilitas belajar terhadap prestasi belajar mata pelajaran UN siswa SMK Negeri 1 Petang. Dengan determinasi sebesar 59,5\%.

Saran yang dapat diajukan dalam penelitian ini adalah sebagai berikut.

Siswa disarankan untuk selalu meningkatkan motivasi berprestasinya agar siswa selalu bersemangat dalam belajar dan tujuan pembelajaran yang direncanakan oleh guru dapat tercapai secara maksimal.

Guru disarankan untuk selalu memberikan pembelajaran yang inovatif dan menyenangkan sehingga motivasi siswa dalam belajar dapat ditingkatkan dan prestasi belajar siswa pun dapat dioptimalkan.

Orang tua disarankan untuk selalu mendukung pendidikan anaknya, agar cita-cita yang dimiliki oleh anaknya dapat tercapai dan anaknya menjadi giat belajar.

Kepala sekolah disarankan untuk memberikan kebijakan-kebijakan yang menunjang pembelajaran di sekolah, terutama dalam pengadaan fasilitas pembelajaran di sekolah.

Peneliti lain disarankan untuk mengembangkan penelitian ini sehingga permasalahan di dunia pendidikan dapat teratasi secara maksimal.

\section{DAFTAR RUJUKAN}

Abu Ahmadi \& Supriyono Widodo. 2004. Psikologi Belajar. Jakarta: PT Rineka. Cipta.

Aryadewi, Ayu Putu Dyah. 2012. Determinan Motivasi Kerja, Status Sosial Ekonomi, dan Pola Asuh Orang Tua Terhadap Niat Berwiraswasta Siswa SMK Pariwisata Triatma Jaya Dalung Kabupaten Badung Propinsi Bali. E-Jurnal Pascasarjana Undiksha Volume 3 Nomor 2.

Gerungan. 1991. Psikologi Sosial. PT. Eresco. Bandung. Faisal

Hamzah. B. Uno. 2013. Teori Motivasi dan Pengukurannya. Jakarta: Bumi Aksara.

Kartono, Kartini, 1985, Bimbingan Belajar di SMA dan Perguruan Tinggi, Jakarta,. CV Rajawali.

Katili, N Sundoro. 2013. Analisis Sarana dan Intensitas Penggunaan Laboratorium Fisika Serta Kontribusinya Terhadap Hasil Belajar Siswa SMA Negeri di Kabupaten Jembrana. E-Jurnal Pascasarjana Undiksha Volume 3 Nomor 1.

McClelland, David. 1976. The Achievement Motive. Irvington Publishers, Inc. New York.

Muhibbin, Syah. 2005. Psikologi Belajar. Jakarta: Raya Grafindo

Sardiman, A.M. 2011. Interaksi dan Motivasi Belajar Mengajar. Jakarta: PT RajaGrafindo Persada.

Sastrayasa, Dewa Putu. 2015. Analisis tentang Biaya Pendidikan Ditinjau dari Status Sosial Ekonomi Orang Tua Siswa Sekolah Dasar di Desa Cemagi dalam Pengaruhnya Terhadap Hasil Belajar Siswa. Tesis. Tidak diterbitkan. Pascasarjana Undiksha.

Siti Partini. 1998. Psikologi Sosial. Yogyakarta: Studing Press.

Sukada, I Ketut. 2013. Kontribusi Minat Belajar, Motivasi Berprestasi dan Kecerdasan Logis Matematika Terhadap Hasil Belajar Matematika Siswa SMA Negeri 1 Kintamani. E-Jurnal Pascasarjana Undiksha Volume 4 Nomor 1. 
JAPI, Vol. 9 No. 1, Bulan Tahun 2018

ISSN: 2613-9561

The Liang Gie. 2002. Cara Belajar yang Efisien. Yogyakarta: Pusat Kemajuan Studi. 